\title{
Introduction. The Science of Television: Television and its Importance for the History of Health and Medicine
}

Jessica Borge, Tricia Close-Koenig, Sandra Schnädelbach*

From the live transmission of daunting surgical operations and accounts of scandals about medicines in the 1950s and 1960s to participatory aerobic workouts and militant AIDS documentaries in the 1980s the interrelationship of the history of bodies and health on television and the history of television can be witnessed. A telling example of this is the US born aerobics movement as it was brought to TV in Europe, with shows such as Gym Tonic (from 1982) in France, Enorm in Form (from 1983) in Germany or the Green Goddess on BBC Breakfast Time (from 1983) in Great Britain. The 1980s aerobic movement was contemporary, similar and yet differing in national broadcast contexts. Television and its evolving formats expressed and staged bodies and health. A history of fitness or physical health, for example, could not be conducted without acknowledging and understanding the role that television played in bringing such fitness programmes into the living room. Be it health-themed magazines, reports on medical firsts and threatening illnesses in the evening or aerobic workouts in the morning, television and its role in imparting the hazards of ill-health and in presenting preventive means is a rich source of twentieth century health practices.

When public broadcasting was restructured and broadened in post-war Europe, television was still a relatively new medium. No one actually knew what its future would be. The institutions, aims, and uses of television were

* The authors acknowledge that the preparation of this article, within the ERC BodyCapital project, received funding from the European Research Council (ERC) under the European Union's Horizon 2020 research and innovation programme (grant agreement No 694817).

Jessica Borge, SAGE UMR7363 Université de Strasbourg, jborge@unistra.fr Tricia Close-Koenig, SAGE UMR7363, Université de Strasbourg, tkoenig@unistra.fr Sandra Schnädelbach, SAGE UMR7363, Université de Strasbourg / Max Planck Institute for Human Development, Berlin, schnaedelbach@mpib-berlin.mpg.de 
under construction: the development of content followed, sometimes as a by-product of technology and technological developments. ${ }^{1}$ In its early days, the television set was by no means established as the home entertainment device we think of today, but was in many ways an object of experimentation. It was imagined and tested as a tool for visual telecommunications, allowing for live screenings and interactions, similar to today's video calls. It also allowed recording and closed circuit communication used for educational purposes, such as school television. ${ }^{2}$ Further, the challenges and the potential of television were tested in the field of science, and more specifically, medicine and health education.

Early pre-televisual moving images from the nineteenth century were deeply entangled with the depiction (and production) of scientific knowledge. ${ }^{3}$ The use of cameras, conceived as the extension or enhancement of the human eye, proved to be especially influential in medical research and education, rendering invisible details of the human body on the screen. ${ }^{4}$ This began with film and micro-cinematography. Film served the aims of propaganda in the war on public health scourges such as syphilis, tuberculosis or alcoholism, battles that would deeply influence health education, conceptions of human capital, and bodily practices through to the interwar period. Continuities and differences arose as moving images progressed from the projector and large screen dispositive to broadcasting studios and television sets which, from the mid-century, could be found in research laboratories, hospitals and medical clinics. ${ }^{5}$ Television screens were increasingly used in classrooms ${ }^{6}$ and they became household fixtures, bringing medical information and health messages into the privatised, domestic sphere.

By the early twentieth century, state welfare had been established in most European countries to varying extents, for example, accident and disability insurance, such as the Bismarckian social and health insurance of late nineteenth century Germany. By the mid-twentieth century, and following two world wars, health increasingly became a state concern, especially after 1945. Public health was ever more important and state health care systems were implemented, i.e., Sécurité Sociale in France (1946) and the National Health Service in Great Britain (1948). These infrastructures were set up in an era of shifting focus of health concerns: from treating and preventing dis-

1 Williams 1974, 29.

2 Horrocks 2018, 730; Powell/Shandley 2016, 35; Hickethier 1998, 9-16; Bourdon 2014.

3 Cf. Gaycken 2015.

4 McLuhan 1964, 2001; Killen 2017; Boon 2008, for the history of television cf. pp. 184-232; Ostherr 2013.

5 Cf. Bashshur/Shannon 2009; Greene 2017.

6 Cf. Orgeron/Orgeron/Streible 2012. 
ease to ensuring and restoring individual well-being. The threat posed by infectious diseases receded, but only to be replaced by chronic conditions linked to lifestyle and individual behaviour.?

Parallel to these changes in concepts and practices for health in the second half of the twentieth century, television made its way into European societies. Before becoming a mass medium with increasingly individualistic consumption practices in the 1960s, educators embraced television in its early years. At the beginning of the 1950s, in the wake of nascent popular education networks, teachers and parishes set up tele-clubs; taking advantage of the advent of a leisure civilisation they provided continuing education to people of all ages. ${ }^{8}$ Similarly, television was welcomed in schools as a means of modernizing education. For example, in France, a dedicated structure was created under the authority of the National Education Department in 1951, which became Radio-Télévision Scolaire in 1962. In addition to supporting classroom teaching, it aimed to present current events and world realities to students. ${ }^{9}$

Throughout the age of television, health and body-related subjects have been presented and diffused into the public sphere through a multitude of concurrent forms: via short films in health education programmes as well as in school television, via professional training films as well as in TV ads, via documentary and reality TV shows as well as in TV news, but also as complementary VHS and similar video formats circulating in private and public spheres. Yet, television's relevance for the history of bodies and health has been little researched. As an everyday object, television has been seen as less intellectually challenging than other historical conduits, such as political history; ${ }^{10}$ television has held a backseat position as a "luxury that embellishes rather than underpins historical arguments". ${ }^{11}$ The majority of research so far accords with this sense that television sits apart from the historian's work, and has been conducted within the field of media studies. ${ }^{12}$ Although, in recent decades scholars in the history of medicine, science, and social history have recognised the centrality of the image, ${ }^{13}$ and, more spe-

7 Rothstein 2003; Bonah/Cantor/Laukötter 2018.

8 Cacérès 1964, 235-236.

9 Television programmes were used as an important part of a larger pedagogical approach, for example, with students subsequently conducting their own inquiries to present to the class. Hourtic 1965; "La télévision dans les classes de transition" 1965.

10 Jordanova 2012, 23.

11 Layton-Jones 2010, 105.

12 For example in France, Mansier/Méadel/Sécail 2014; Mansier 2014. For Germany see, Vüllers, 2002; Brünner 2011; with regard to public health but without a historical focus: Jazbinsek 2000, especially: Appel 2000.

13 Porter 1988. 
cifically, of television, to the public understanding of (and engagement in) health and healthcare cultures, the uptake has been slow. The cross-disciplinary interest in television can, however, open an important window into the history of health practices and health consumerism over the twentieth century. This has proven fruitful in cases of visual research in the examination of films on sex hygiene within the history of venereal diseases in the first half of the twentieth century ${ }^{14}$ or in the ongoing work on television and the theme of human reproduction. ${ }^{15}$

With respect to visual sources and cross-disciplinary approaches, this special issue aims to introduce the emerging field of health-related audio-visuals to medical historians by presenting case studies that identify and unpack the centrality of television for the history of medicine and health, herein bridging the gap. In doing so, we work from the premise that visuals are not conceived merely as a mirror or expression of what is observed, but should be regarded as a distinct, interactive, and performative power of mass media societies; in other words, our position is that visuals have changed body politics, healthy-self perceptions, and the practices of individuals in European market-based societies. Our objective in the assembly of this special issue is to understand the role that modern visual mass media has played in the transition from national bio-political public health paradigms to contemporary societal forms, where better and healthier life is increasingly shaped by market forces, and embodied by what is heard and seen. ${ }^{16}$

In this introduction, we offer points of entry for the combined study of TV audio-visuals and health by outlining benchmarks of television history and related archival research in Germany, Great Britain, and France, which (as we understand it) may be less familiar to historians of science and medicine at this time. In offering these frameworks, contextual details, and points of reference, we aim to broaden the discussion of relationships between television, medicine and health. This is a strand of history that, we believe and hope, will create possibilities for new findings, and new narrative pathways in twentieth century history.

14 Bonah/Laukötter 2015; Bonah 2015; Danet 2015; Laukötter 2015; Winkler 2015; Bonah/ Cantor/Laukötter 2018.

15 Borge 2017; Dow 2019; Gregory 2015; Olszynko-Gryn 2017; Parry 2013.

16 This premise underpins the on-going work of our research group in the ERC funded project "The healthy self as body capital: individuals, market-based societies and body politics in visual twentieth century Europe" led by Christian Bonah (Université de Strasbourg) and Anja Laukötter (MPIHD, Berlin). 


\section{Television in Europe}

Histories of television in Europe are themselves national histories, as technological processes do not prone over social processes; or according to Raymond Williams "the setting of limits and the exertion of pressures, within which variable social practices are [...] affected." 17 Prior to today's growth of cross-national, on-demand streaming services such as Netflix, for example, broadcasting, its supporting institutions, and televisual content were historically structured upon (and reflected) defined societies, economies, and political belief systems: electronic frequencies or "bandwidth" were commoditised, redistributed, and restricted according to geographical boundaries. After experiments with TV in the first decades of the twentieth century in most European states, the years abutting the Second World War were decisive for setting up structures that still shape television landscapes today. The birth and development of national television networks and programmes were influenced by national cultural and political specificities. ${ }^{18}$

In Germany, the history of television in the second half of the twentieth century is marked by the country's divide following the Second World War. Whereas in the socialist German Democratic Republic (GDR), television broadcasting was part of a state controlled media structure that permitted just one channel until 1969, the federally organized West (Federal Republic of Germany, FRG) provided a more complex system of regional and national public channels. And yet, in an atmosphere of political and cultural competition, both states constantly referenced each other. Whereas most East Germans could receive Western television and vice versa, ${ }^{19}$ programming produced by and for the German neighbours was of special interest. ${ }^{20}$

Regular television broadcasting in the GDR began in 1952, on the symbolically charged day of 21 December, Joseph Stalin's birthday, with two hours of daily programming. At this time watching television was a communal event: until the mid 1950s, only one in every hundred households owned a TV and broadcast content was limited to 22 hours per week. In 1956, Deutscher Fernsehfunk (DFF) ${ }^{21}$ was launched, increasing weekly output to 58 hours. In 1969, a second channel, DFF-2, was introduced together with

17 Williams 1974, 130.

18 Equally there is a history of European television, this is not explored here but that must be acknowledged. Its history traces the political specificities of Europe and an opposition to American television, for example with the European Broadcasting Union and Eurovision programmes. Cf. Coleman/Rollet 1997; Bourdon 2011; Bignell/Fickers 2008.

19 In the 1960s, the reception of Eastern programmes in the West ceased.

20 Dussel 2010, 123-136.

21 Renamed Fernsehen der DDR in 1972. 
colour TV. ${ }^{22}$ The following decade then brought about a differentiation and diversification of television programming in East and West that allowed for innovation, even in the generally more restrictive structures of the East German broadcasters. ${ }^{23}$

Competing with the GDR, the Western German public broadcasting service, Arbeitsgemeinschaft der öffentlich-rechtlichen Rundfunkanstalten der Bundesrepublik Deutschland (ARD), also started broadcasting in 1952, albeit four days later than the GDR. Founded in 1950 for radio and television programming, this federal consortium of local public broadcasting services was independent from state control and non-commercial. ${ }^{24}$ Following conflicting federal and national media interests, a second channel, Zweites Deutsches Fernsehen (ZDF), was founded to centrally govern nationwide broadcasts in 1963. One year later regionally diverse third channels followed. It was also in this decade that television developed into a mass medium. The prevalence of TV sets and their popular usage evolved at similar rates in the West and East. In the early 1960s about a quarter of the population owned a TV: ten years later the number had risen to about three quarters. In addition to the introduction of colour TV in West Germany in 1967, a second major shift took place in 1984 when private broadcasting companies entered the scene and paved the way for a commercialized television landscape. However, following the reunification of Germany, the broadcasting system was restructured in 1992, with the West German mix of public and private broadcasting companies being applied nationwide. ${ }^{25}$

In Britain, television has, for most of its history, been divided between commercial and public service broadcasting. ${ }^{26}$ The British Broadcasting Corporation (BBC) launched the first regular (though largely experimental) television service in 1936, which was confined to around four hours per day in the London area only. Transmission was suspended during the war, resuming in 1946, when a TV licence was introduced to fund programming, although, at this stage, the $\mathrm{BBC}$ remained focussed on radio. The live broadcast of the coronation of Queen Elizabeth II in 1953 triggered a dramatic rise in television set ownership, which increased to about 20 per cent of households (or 81 sets per thousand population) by 1954. This put British TV ownership ahead of Europe, where the next highest proportion was Bel-

22 Steinmetz/Viehoff 2008, pp. 68-73; Schubert/Stiehler 2007, 26.

23 Cf. Steinmetz 2016, 133-154.

24 On a small scale, public television broadcasting had already begun in the late 1920s and was further developed during National Socialism.

25 Cf. Steinmetz 2016, 133-154; Dussel 2010, 136-143, 263-267.

26 For comprehensive work on this subject, see Briggs 1961-1996. See also Turnock 2007; Holmes, 2008. 
gium (with 5 sets per thousand). ${ }^{27} \mathrm{~A}$ second, commercial channel was introduced in 1955. This was organised as a series of separately owned regional franchises known collectively as Independent Television (ITV) using an advertising model for bringing in revenue and funding content. 'Television households' exceeded 'radio households' by the end of the 1950s. Increased broadcasting time per week and the considerable production costs led, by the 1960s, to the licensing and exchange of TV programmes at the international level. ${ }^{28}$ Competition between TV channels and audience polls meant that American serials featured regularly on the commercial channel, although the majority of programming was produced in Britain. Regulation improved the standard of programming on both channels.

The third British television channel, BBC2, was launched in 1964, and by 1969 all three channels were transmitting in colour, although many people watched in black and white. Channel 4 was launched in 1982 as a non-profit network with a public service remit, which nonetheless took revenue from advertising. The following decade saw a radical shift with the 1990 Broadcasting Act and subsequent legislation, which significantly deregulated British television, leading to greater competition and variety of content. Satellite television joined broadcasting institutions and was popularised through the purchase of sporting franchises, and the sale of subscriptions to consumers. Public Service Broadcasters have historically produced most of the televisual content in Britain, and have been subject to minimum quotas and guidance on, for example, minimum amounts of news and current affairs programming, and content made by independent producers. Britain is also a significant exporter of both programmes and formats. ${ }^{29}$

From its early years, television in France represented both a propaganda challenge and a field for formal and editorial experimentation; it was instructed by the State and implemented by pioneering and ambitious journalists. Although the first experimental broadcasts in France began in 1931, television was established at the end of the Second World War with the renewal of Radiodiffusion française in 1944 (RDF and from 1949 Radiodiffusion-télévision française, RTF) and had become a mass medium by the end of the $1950 \mathrm{~s} .{ }^{30}$ RTF was set up by the Ministry of Information as a public

27 Tunstall 1987, 33 n.3.

28 With the goal of developing, broadcasting and exchanging programmes of a cultural nature, the International Radio Union created a film library and became the International Radio and Television Union in 1961. For more information, see http://www.urti.org/history (Accessed 4 September 2019).

29 House of Lords Communications Committee 2010.

30 On the history of television in France, see Brochard 1994; Sauvage/Veyrat-Masson 2012; Gaillard 2012. 
body to ensure the construction of technical installations, to collect the licence fee that financed the television activity, and to produce and broadcast programmes. The success of television continued to grow over the next decade: while one million French people owned a television in 1958, by 1968 ownership topped nine million. ${ }^{31}$ Television created a new relationship with information and culture, especially since its capacity to produce content had rapidly increased, from a total of 2450 hours of programme time in 1958, 5580 hours in 1968, to more than 8000 hours in $1974 .{ }^{32}$ This increase can be explained in particular by the launch of the second channel (Deuxième chaîne de l'ORTF, from 1975 Antenne 2) in 1964 and the third channel (Troisième chaîne de l'ORTF, from 1975 France Régions 3) at the end of 1972 , in the effort to structure and segment programmes in light of the social and territorial realities of the population.

However, of the three watchwords associated with television, "inform, educate, and entertain", ${ }^{33}$ it is the latter that has prevailed in market logic in French television, with the introduction of advertising in 1968, and privatization from the 1980s onwards (i.e., with Canal+ in 1984, La Cinq in 1986, M6 in 1987). This evolution of television, which is common to all three national contexts, brings to light the relevance of television for public communication. Over the second half of the twentieth century, it has shifted from a controlled (or one-directional) medium to an audio-visual presence capable of multi-faceted interaction with instances of moderation, guaranteed programming and as a vehicle to/for national heritage. This is what media theorist Marshall McLuhan conceptualised loosely as "hot" (one-directional) and "cool" (interactive) media, television having become, by the 1960s, "cool". ${ }^{34}$

This special issue presents national stories of health and television, collected with the understanding that television history is broadly defined along national boundaries, as described above. Yet, the significance of transnational trajectories and trends is central to a European history of health and television that we aim to promote and encourage with this issue. Aligning national with broader perspectives is no easy matter, especially considering that archiving practices relating to television have been subject to national specificities and politics.

31 In 1954, France ranked the third highest in Europe for TV set ownership after Britain and Belgium, at 3 per thousand persons. Tunstall 1987, 33 n.3.

32 Sauvage/Veyrat-Masson 2012, 66.

33 The popularization of this frequently used phrase is attributed John Reith, the first DirectorGeneral of the BBC, who used it to describe the BBC's remit in 1927. Siân 2015, 325.

34 McLuhan, 2001, 24-35; See also interview with McLuhan "Hot and cool media (1965)," https://www.youtube.com/watch?v=J3n65fa40JM (Accessed 4 September 2019). 
In Britain, for example, the majority of early programming was not kept, or was wiped. Apart from short demonstrations, which were transferred to film, no broadcast TV from before 1947 was recorded, partially because there was no need to preserve live transmissions, and also because there was no means to tape/record it. Thereafter, recording involved a film camera taping a monitor; this was expensive and was not widely used. For all intents and purposes, broadcast television was very much a live medium until the introduction of professional videotape in the 1960s. However, video was not seen as a long-term format and tape was re-used multiple times, resulting in what has been called the "catastrophic" loss of programmes. ${ }^{35}$ Accordingly, archival research is challenging. The British Film Institute holds a complete record of BBC output from 1990 onwards, and the BBC has a written archives centre in Caversham, Reading, that is available to researchers by appointment. At the time of writing, there is no public catalogue for BBC document sources. Excluding those that have been repeated on television or otherwise made available through, for example, DVD releases or streaming, extant BBC programmes from before 1990 are not made available for academic research. ${ }^{36}$ However, the BBC, along with ITN (Independent Television News), have recently entered a partnership with Getty Images to manage their online content and their offline archive, meaning that although access is currently difficult (or even impossible) for academic researchers, it might improve in the near future. ${ }^{37}$ Details on other current resources can also be found via the British Universities Film and Video Council. ${ }^{38}$

In Germany, the archival situation is very different for GDR and FRG sources. As the East German state and its broadcasters no longer exist, the sources are now part of historical archives and are more easily accessible than the West German ones. The most comprehensive collection of GDR material is held at the Deutsches Rundfunkarchiv in Potsdam-Babelsberg. Here about 60 per cent of broadcast programming is kept and organized in a database accessible on site. In addition, for health-related material, the collection of Deutsches Hygiene Museum in Dresden offers a variety of documentaries and educational films that were aired on television.

For West Germany, the situation is much more complicated. Broadcast archives do not follow national archive regulations, but are structured for the day-to-day usage and needs of the state independent broadcasting ser-

35 Bryant 2010, 60; Dussel 2010, 165; Kavanagh/Lee 2010, 70.

36 Smart/Wrigley 2016.

37 "BBC Motion Gallery," Getty Images, https://www.gettyimages.co.uk/footage/ bbcmotiongallery; "ITN Source," Getty Images, https://www.gettyimages.co.uk/ resources/itncollection.

38 British Universities Film \& Video Council, http://bufvc.ac.uk/.

Gesnerus 76 (2019) 
vices. These archives are not open to academic researchers, but access can be requested and negotiated. Like the broadcasting landscape itself, the archives are organized regionally. The ARD material is spread over their nine regional offices, the Landesrundfunkanstalten, the Westdeutscher Rundfunk (WDR) being the biggest one with its headquarters in Cologne. For these sources, as well as for productions of the ZDF based in Mainz, the Deutsches Rundfunkarchiv can be a first entry point to gain information on existing archives and on how to organize research. ${ }^{39}$

In France, and in contrast to Germany and Great Britain, the presence of the State and the centralized organization of the television economy, especially before the 1980 s, was not only conceived to direct production and broadcasting, but also provided systematic archiving of programmes. Established in 1974, the Institut National de l'Audiovisuel (INA) was founded to preserve and document the productions of the public television channels. INA holds television archives from about 1940: ${ }^{40}$ this includes audiovisual archives, as well as photographs and document archives. This was expanded in 1992, when INA became responsible for the legal deposit of radio and television productions, meaning that INA archived all productions from every channel. A digitisation plan launched in the 2000s ensured the preservation of the collections and greatly facilitated their access. Putting these digitised programmes online has made them available to the public, either directly or by obtaining approval, notably as education and research have a place in INA's mandate. ${ }^{41}$

It is clear that these national provisions contribute to the construction of collective memories of television broadcasting, simultaneously creating a socially specific sense of the "period eye". ${ }^{42}$ The national collections mentioned above continue to inspire historical research initiatives, and such commentaries deepen our understanding of the physical material contained within $\mathrm{AV}$ archives, as well as the formal editorial decisions that created and developed the collections in the first place. Our intention in outlining the above national perspectives is to facilitate new research in these areas and to clarify the challenges of transnational research; challenges that might be perceived as barriers but which can be breached. Herein, and national boundaries notwithstanding, we must continue to ask: what are the unifying factors? Where can we find the parallel trends and comparative themes that have carried these national histories of television forward, and brought them

39 For an overview of the archives see Behmer/Bernard/Hasselbring 2014.

40 Albeit, as described above, early live programming was not recorded.

41 Institut national de l'audiovisuel, https://institut.ina.fr/.

42 Jordanova 2012, 121. 
together whilst retaining their specific limits and pressures? Since its first demonstration on 26 January 1926, when John Logie Baird transmitted a 30-line image of his business partner, Oliver Hutchinson, to the Royal Society, television has been concerned with projecting the image of the human body in speech and action. ${ }^{43}$ The technology has evolved in parallel with the provision of socialised medicine, the expansion of public health services, and the continued monetization of medical and pseudo-medical services, devices, medicines, and practices. Our answer, then, is that the staging of science, bodies, and health, provide the enduring and unifying thematic link bonding the histories of television in Europe.

\section{Television Visuals: Staging Science, Bodies, and Health}

As with all new media, the rise of television was accompanied by optimistic, even utopian ideas about its impact as well as by waves of concern and criticism regarding possible negative effects on viewers, and society in general. ${ }^{44}$ As the papers in this issue convey, television broadcasts addressed questions of body, health and disease from its earliest days, be it in form of news reports, medical advice magazines, health education films, medical teaching films or school television - not to mention fictional productions, such as the medical soap opera. Television was discussed and used as a promotional tool, was perceived as progressive and even emancipatory to varying degrees, and at the same time it gave rise to concerns on the bodily effects and health related impacts of media (over)consumption.

As this issue aptly illustrates, the history of broadcasting health and disease and the entanglement of television, health and medicine, is more than an episode in the history of film and medicine: with its focus on live broadcasting and its potential to connect the (scientific) world with the domestic sphere, television offered a new 'dispositif', a new mode of reception as well as structuring perception, and yet could rely on an old visual tradition. ${ }^{45}$ In the 1990s, the history and sociology of science, technology and medicine took a 'visual turn', retracing medicine's visual culture and analysing visual representations of medicine, health and health professionals. ${ }^{46}$ This, however, resulted in the isolation of television visuals. Whereas attention to screen media as an object of historical enquiry in the service of the history of medicine,

43 Sims 2019.

44 Dant 2012.

45 On the dispositif of television see Hickethier 1998, 10-13.

46 Cf. Cartwright 1995; Pernick, 1996. 
the body, society, and health has been growing in recent years, the explicit use/participation of television remains under-represented. ${ }^{47}$ In addressing the gap, this themed issue aims to investigate how television programmes approached the subject of medical progress and its limitations, as well as the idea of healthy behaviour, as they were adapted to television formats. We ask how similar yet differing national broadcast contexts shaped and staged bodies and health in varying ways and how the evolution of televisual editing, especially its adaptation to consumer/market logic, changed health messages and practices from the 1950s to the 2000s. In using this approach, it is our aim to open dialogue between the history of medicine and health with televisual media history. Our position is that audio-visuals are not to be conceived of merely as channels of information, but that they are an active, moreover 'interactive' power in mass media societies. Herein, we understand histories of "broadcasting health and disease" as a central element of the reciprocal relationship between medical knowledge/practices and media.

This issue explores television and medicine in their functions for - and creations by - society. The contributions are structured by their regional focus but share thematic/analytical approaches that convey manifold interconnections and reference points which, as we shall see, cross national and cultural borders. They unfold three overarching categories: Creating Television, Creating the Viewer, and Creating Science.

\section{Creating Television}

To fully understand the role of "broadcasting health and disease" in the second half of the twentieth century, it is necessary to enquire into the medium's preconditions: How were television programmes produced, how did technical developments enable new definitions and usages of the medium and shape new contents? How did these contexts form the ways in which bodies, health and science were presented and how did the specificities of health education and medicine contribute to creating television as we know it?

In this vein, SUSANNE VOLLBERG's paper shows how the production process of health magazines in East and West Germany were marked by various challenges. She introduces this genre as the main format for dealing with health-related topics in East and West German television from the 1960s to the 1980s. The extremely popular magazines made use of a mix of

47 Some of the rare examples are Boon 2008; Ostherr 2013; Bonah 2020; Boon 2020; Laukötter 2020; Lury 2020. 
genre elements that combined features of the traditional health education film but also added features like quizzes, an anchor person and discussion panels that gained special popularity in the context of a growing debate culture from the 1960s on. Concerning production, however, medical and media sphere were not always in agreement. This was largely due to the impact that television programmes had: doctors noted a significant raise of patient visits after health magazine broadcasts and complained about unqualified assumptions and questions. Television, Vollberg claims, created a public awareness of health issues, which developed in constant exchange with the shaping of television as a medium. West Germany's most popular magazine, for example, was discontinued when it was no longer compatible with the decentralized broadcasting landscape of the 1980s. The prior "faith in the demi-gods in white" was now seen as a relic of an overly hierarchical and lecturing media system.

In examining closed-circuit (rather than public) television, ANGELA SAWARD looks at the genesis and work of the University of London Audio-Visual Centre, which produced a large corpus of postgraduate medical educational programmes between 1971 and 1991, including such titles as The Scientific Basis of Medicine, Muscle Fatigue, and The Causes of Obesity. It is argued that this archive, held at Wellcome Collection, London, democratised the pedagogical experience of students engaged in medical disciplines. The corpus is also considered in respect of obsolescence and redundancy, in terms of both the content of video-lectures (which in medicine became quickly out-dated) and also in respect of video formats, which affected re-distribution to later generations of medical postgraduates. These videos are shown to pose unique challenges for the archivist specialising in both audio-visuals and the history of medicine.

To broaden our understanding of a televisual grammar, TIM BOON and JEAN-BAPTISTE GOUYON inquire into medically-themed episodes of the BBC documentary series Horizon, comparing them with natural history documentaries from the late 1950s to the 1980s. They analyse programme styles to explore to what extent they are responsible for establishing a distinctive relationship to the practice of medicine, which they conceptualise as the "inscribed patient". Central to the style of medical programmes is a hierarchical structure, transferring agency mainly to experts. The "inscribed patient" has been used to show viewers how to behave as patients, and as the subject of medical interventions. Yet, many kinds of documentary television, they argue, share a specific mode of address that aims to prompt the viewer to adopt certain kinds of behaviour. This finding is closely tied with the second category in this special issue: Creating the Viewer. 


\section{Creating the Viewer}

Just as naturalist documentaries give a certain agency to viewers as potential participants in wildlife filmmaking, BOON and GOUYON claim, medical programmes propose the audience to engage in specific ways. Viewers are invited to identify as 'patients' and are provided with role models for medical interactions. Based on the "inscribed patient", television not only contributes to the modelling of doctor-patient relationships but also actively shapes its audience. This perspective on the creation of the viewer is a second important layer of the contributions in this issue. What do we know about television reception and its (widely believed) effects? How did health programmes use knowledge about the viewer and in what ways did they transfer into new practices?

Addressing these questions through the history of cardiovascular disease prevention in the German Democratic Republic (GDR), STEFAN OFFERMANN tells us how health education looked at creating a healthy television audience that would not fall victim to excessive viewership, and herein at creating healthy socialist bodies. In this story, television is both an instrument and an object of health prevention. Through psycho-physiological, audience and opinion research, the effects of television on viewers were examined and then taken up in health education films. Offermann addresses the medicalization of TV usage and of the viewer.

\section{Creating Science}

Focussing on the viewer and their practices is one means through which it can be observed how television shaped the reception of, knowledge about, and implementation of health and medicine in everyday life. Further, TV proved to be a powerful ally of medicine. Making use of television's potential in documentary narration, health-related programmes actively validated and contributed to the creation of a public image of science, and the acceptance of medical practices.

PHILIPPE CHAVOT and ANNE MASSERAN tell the story of appreciation or worth in advancements in medical practice and television. They trace an evolving/developing relationship between television media, surgeons and patient families with regard to heart transplantation in France between 1968 and 1973, a five-year period that includes two waves of heart transplant surgeries. Television not only reported on the surgeries, their successes and their stories, but brought storytelling and emotional narratives into the portrayals such that television became an influential ally in the promotion for graft med- 
icine at a time when it was not wholly established. Not only did television reports support innovative work in this field of medical science, but also the reporting techniques used for them were innovative for television. In this paper, the interactions between the medical sphere and the media sphere are played out, with television effectively contributing to the on-going scientific work.

\section{The Science of Television: Television's Entanglements with Health Beyond Information and Education}

Whilst this special issue is broad in scope, it is necessarily bound by limitations. The following articles present case studies from East and West Germany, Great Britain, and France; they consider 'utility' or non-fiction productions, that is educational, public service, news-casts, talk shows and current affairs programmes (aka, magazines); their temporal scope is restricted to the late 1950s through to the early 1990s, from the establishment of television as mass media and ending before its digitalisation. The articles open questions on the multi-faceted relationship between television and health that can (and should) be pursued, expanded and complemented with further research and with more cases in these (and other) national contexts. For example, we can further explore the question of how television plays into narratives of legitimacy and how legitimacy or authority is created on medical and health issues regionally, nationally, and transnationally and with regard to cultural and political differences. As the articles in this issue demonstrate, the influences were reciprocal: television was not only an instrument that was shaped following medicine's needs but the specificities of the medium also contributed to the ways body, health, and medical science were reflected and defined in society. With its potential to bring the moving image into the domestic sphere, to bring the bodies of doctors and patients into the living room, television had the power to stabilize but also to destabilize popular evaluations of medicine and health - effects that often came as a surprise to the producers and were by no means completely under their control. Herein, we can observe that television is not only a tool or an instrument of politics or medicine, but that it shapes (and is shaped by) society, on local and global levels.

Television was an important device for the broadcast of information on health and disease, but it was more than this. As the papers presented here show, televisual technologies were part and parcel of Western health science and education trajectories of the twentieth century. Not only did they support and accompany the trajectory of change in dealing with and communicating about health and disease, but as this issue aims to explore, audio-visual media actively formed 
contemporary understandings of bodily norms and, thereby, standards of treatment and concepts of medical, as well as individual, responsibility. These articles examine how spectators were invited not only to be TV consumers, but how TV programmes and TV set-ups integrated and sometimes pretended to transform the viewer into a participant of the show. In short, TV programmes spread the conviction that subjects had the ability to create their own body.

\section{Bibliography}

"La télévision dans les classes de transition", Bulletin de la Radio-Télévision Scolaire 25 (1965) 31

"The British film and television industries-decline or opportunity?" House of Lords Select Committee on Communications, $1^{\text {st }}$ Report of Session 2009-10 (London 2010) URL: https://publications.parliament.uk/pa/ld200910/ldselect/ldcomuni/37/37i.pdf

Appel, Andrea J., "Patentrezepte per TV. Die Gesundheits- und Krankheitsvorstellungen in einschlägigen Informations- und Ratgebersendungen", in Jazbinsek, Dietmar (Hrsg.), Gesundheitskommunikation (Wiesbaden 2000) 96-114

Bashshur, Rashid L./Gary W. Shannon, History of Telemedicine: Evolution, Content, and Transformation (New Rochelle 2009)

Behmer, Markus/Birgit Bernard/Bettina Hasselbring (Hrsg.), Das Gedächtnis des Rundfunks. Die Archive der öffentlich-rechtlichen Sender und ihre Bedeutung für die Forschung (Wiesbaden 2014)

Bignell, Jonathan/Andreas Fickers (eds.), A European Television History (Oxford 2008)

Bonah, Christian, "'A word from man to man'. Interwar Venereal Disease Education Films for Military Audiences in France”, Gesnerus 72/1 (2015) 15-38

Bonah, Christian/David Cantor/Anja Laukötter (eds.), Health Education Films in the Twentieth Century (Rochester 2018)

Bonah, Christian/Anja Laukötter, "Introduction: Screening Diseases: Films on Sex Hygiene in Germany and France in the First Half of the $20^{\text {th }}$ Century", Gesnerus 72/1 (2015) 5-14

Bonah, Christian/Anja Laukötter (eds.), Body, Capital \& Screens. Moving Images and Individual's Health in Economy-based Twentieth Century Societies (Amsterdam 2020)

Bonah, Christian, "Let's Talk about S...: The Influence of Cinema Verité on Sex Education in French National Television around 1968", in Bonah, Christian/Anja Laukötter (eds.), Body, Capital \& Screens. Moving Images and Individual's Health in Economy-based Twentieth Century Societies (Amsterdam 2020) 57-78

Boon, Timothy, Films of Fact: A History of Science in Documentary Films and Television (London 2008)

Boon, Timothy M., "Playing the Doctor, Playing the Patient: The Performance of Health Identities in Live Medical Television, 1958", in Bonah, Christian/Anja Laukötter (eds.), Body, Capital \& Screens. Moving Images and Individual's Health in Economy-based Twentieth Century Societies (Amsterdam 2020) 19-34

Borge, Jessica, "Propagating Progress and Circumventing Harm", in Maierhofer, Waltraud/Beth Widmaier Capo (eds.), Reproductive Rights Issues in Popular Media: International Perspectives (Jefferson 2017) 11-28 
Bourdon, Jérôme, Du service public à la télé-réalité. Une histoire culturelle des télévisions européennes, 1950-2010 (Bry-Sur-Marne 2011)

Bourdon, Jérôme, Histoire de la télévision sous de Gaulle (Paris 2014)

Briggs, Asa, The History of Broadcasting in the United Kingdom (6 vols., Oxford 1961-1996)

Brochand, Christian, Histoire générale de la radio et de la télévision en France (Paris 1994)

Bryant, Steve, "National Television Archives and Their Role", Critical Studies in Television 5 (2010) 60-67

Brünner, Gisela, Gesundheit durchs Fernsehen. Linguistische Untersuchungen zur Vermittlung medizinischen Wissens und Aufklärung in Gesundheitssendungen (Duisburg 2011)

Cartwright, Lisa, Screening the body. Tracing medicine visual culture (Minneapolis 1995)

Coleman, James A./ Brigitte Rollet (eds.), Television in Europe (Exeter 1997)

Cacérès, Benigno, Histoire de l'éducation populaire (Paris 1964)

Danet, Joël, "Representation of Dangerous Sexuality in Interwar Non-Fiction Sex Hygiene Films in the Interwar Period: A Franco-German Comparison", Gesnerus 72/1 (2015) 39-55

Dant, Tim, Television and the moral imaginary: Society through the small screen (Basingstoke 2012)

Dow, Katherine, "Looking into the Test Tube: The Birth of IVF on British Television", Medical History 63/2 (2019) 189-208

Dussel, Konrad, Deutsche Rundfunkgeschichte (Konstanz 2010)

Dutta, Kunal, "UK's final analogue signal switched off: You have been watching, for the last 76 years...", Independent online, 24 October 2012. URL: https://www. independent.co.uk/arts-entertainment/tv/news/uks-final-analogue-tv-signal-switched -off-you-have-been-watching-for-the-last-76-years-8225396.html (Accessed 4 September 2019)

Gaillard, Isabelle, La télévision. Histoire d'un objet de consommation, 1945-1985 (Bry-sur-Marne 2012)

Gaycken, Oliver, Devices of Curiosity. Early Cinema and Popular Science (Oxford 2015)

Greene, Jeremy A., "When Television was a Medical Device", Humanities. The Magazine of the National Endowment of the Humanities 38/2 (2017) URL: https:// www.neh.gov/humanities/2017/spring/feature/when-television-was-medical-device (Accessed 4 September 2019)

Gregory, Mara, “'Beamed Directly to the Children': School Broadcasting and Sex Education in Britain in the 1960s and 1970s", Transactions of the Royal Historical Society 25 (2015) 187-214

Hickethier, Knut, Geschichte des deutschen Fernsehens (Stuttgart/Weimar 1998)

Holmes, Su, Entertaining television. The BBC and popular culture in the 1950s (Manchester 2008)

Horrocks, Chris, The joy of sets: A short history of the television (London 2018)

Hourtic, M. "Comment nous exploitons une émission de télévision scolaire", Bulletin de la radio-télévision scolaire 19 (1965) 20

Jordanova, Ludmilla, The Look of the Past. Visual and Material Evidence in Historical Practice (Cambridge 2012) 
Jazbinsek, Dietmar (ed.), Gesundheitskommunikation (Wiesbaden 2000)

Kavanagh, Jacquie/Adam Lee, "Accessing TV History: Accessing BBC Archives", Critical Studies in Television 5 (2010) 68-72

Killen, Andreas, Homo Cinematicus: Science, Motion Pictures, and the Making of Modern Germany (Philadelphia 2017)

Laukötter, Anja, "Listen and Watch: The Practice of Lecturing and the Epistemological Status of Sex Education Films in Germany", Gesnerus 72/1 (2015) 56-76.

Laukötter, Anja, “'One Feels so Much in These Times!': Emotional Education and the Construction of New Subjectivities: Sex Education Films in Early 1960s GDR", in Bonah, Christian/Anja Laukötter (eds.), Body, Capital \& Screens. Moving Images and Individual's Health in Economy-based Twentieth Century Societies (Amsterdam 2020) 129-148

Layton-Jones, Katy, "Introduction: Visual Collections as Historical Evidence”, Visual Resources. An International Journal of Documentation 24 (2010) 105-107

Lury, Karen, "The BBC's Children in Need Telethon: The Currencies of Compassion", in Bonah, Christian/Anja Laukötter (eds.), Body, Capital \& Screens. Moving Images and Individual's Health in Economy-based Twentieth Century Societies (Amsterdam 2020) 34-56

Mansier, Pascale, "Les magazines de santé à la télévision depuis les années 1950", Le Temps des médias 23/2 (2014) 241-244

Mansier, Pascale/Cécile Méadel/Claire Sécail, "Présentation: Santé à la Une", Le Temps des médias 23/2 (2014) 5-12

McLuhan, Marshall, Understanding Media: The Extensions of Man (London 1964, 2001)

Olszynko-Gryn, Jesse, "Thin blue lines: product placement and the drama of pregnancy testing in British cinema and television", British Journal for the History of Science 50/3 (2017) 495-520

Orgeron, Devis/Marsha Orgeron/Dan Streible (eds.), Learning with the Lights Off. Educational Film in the United States (Oxford 2012)

Ostherr, Kirsten, Medical Visions: Producing the Patient through Film, Television and Imaging Technologies (Oxford 2013)

Parry, Manon, Broadcasting Birth Control: Mass Media and Family Planning (New Brunswick, N.J. 2013)

Pernick, Martin, The black stork: Eugenics and the death of "defective" babies in American medicine and motion pictures since 1915 (New York, 1996)

Porter, Roy, "Seeing the Past", Past and Present 118 (1988) 186-205

Powell, Larson/Robert Shandley (eds.), German Television. Historical and Theoretical Perspectives (New York/Oxford 2016)

Rothstein, William, Public Health and the Risk Factor: A History of an Uneven Medical Revolution (New York 2003)

Sauvage, Monique/Isabelle Veyrat-Masson, Histoire de la télévision française de 1935 à nos jours (Paris 2012)

Schubert, Markus/Hans-Jörg Stiehler, "Programmentwicklung im DDR-Fernsehen zwischen 1953 und 1963. Programmstrukturanalytische Betrachtungen zu den Anfängen des DDR-Fernsehens", in Dittmar, Claudia/Susanne Vollberg (Hrsg.), Zwischen Experiment und Etablierung: Die Programmentwicklung des DDR-Fernsehens 1958 bis 1963 (Leipzig 2007) 25-63 
Siân, Nicholas, "The Reithian legacy and contemporary public service ethos", in Conboy, Martin/John Steel (eds.), The Routledge Companion to British Media History (London/New York 2015) 323-333

Sims, Alexandra. "See the first TV image from John Logie Baird's early 'Televisor' demonstrations" Independent online, 26 January 2016. URL: https://www. independent.co.uk/life-style/gadgets-and-tech/news/see-the-first-tv-imagefrom-john-logie-bairds-early-televisor-demonstrations-a6834416.html (Accessed 4 September 2019)

Smart, Billy/Amanda Wrigley, "Television History: Archives, Excavation and the Future. A Discussion", Critical Studies in Television: The International Journal of Television Studies 11 (2016) 96-109

Steinmetz, Rüdiger, "Television History in Germany. Media-Political and MediaEthical Aspects" in Powell, Larson/Robert Shandley (eds.), German Television. Historical and Theoretical Perspectives (New York/Oxford 2016) 133-154

Steinmetz, Rüdiger/Reinhold Viehoff (Hrsg.), Deutsches Fernsehen Ost. Eine Programmgeschichte des DDR-Fernsehens (Berlin 2008)

Tunstall, Jeremy, The Media in Britain (London 1983/1987)

Turnock, Rob, Television and Consumer Culture. Britain and the Transformation of Modernity (London 2007)

Vüllers, Claudia, "Mens sana in corpore sano": Gesundheit in der Fernsehwerbung (Hagen 2002)

Williams, Raymond, Television: Technology and Cultural Form (Glasgow 1974)

Winkler, Anita, "Debating Sex: Education Films and Sexual Morality for the Young in Post-War Germany, 1945-1955", Gesnerus 72/1 (2015) 77-93 